\title{
TEKNIK PEER-REVIEW MELALUI GOOGLE DOCS: ALTERNATIF PIRANTI KOLABORASI DALAM MENULIS
}

\author{
Umi Sholihah \\ Universitas Widya Dharma Klaten \\ e-mail: umi.s@unwidha.id
}

\begin{abstract}
The digital era requires us to always be creative and innovative. As an educator, we must also be creative and innovative to find new innovations in learning. One of the innovations in learning is by utilizing the Google Docs application. This paper is based on classroom action research on the use of the Google Docs application to support the use of Peer-Review technique in writing for English department students of Widya Dharma University of Klaten. The results of the study show that the Peer-Review technique by utilizing the Google Docs application in writing can 1) train students to think critically, observantly, and thoroughly when reviewing their friends' writing which can automatically improve their own writing skills; 2) increase the ability to collaborate and work together to have global competitiveness in the $21^{\text {st }}$ century; 3 ) motivate students to be active in completing writing assignments; 4) make learning in the classroom more meaningful by creating a more lively classroom situation; 5) make students feel more enjoying and active in writing; 6) save paper usage; 7) provide allowance to students for whenever and wherever they want to review the writing of their friends without having to be bound by time and place when learning to write in class; 8) can boost the sharpness of student analysis so that it can be used also in other fields of study.
\end{abstract}

Keywords: Peer-Review Technique, Google Docs Application, Writing Skills

\begin{abstract}
Abstrak
Era digital menuntut kita untuk selalu berinovasi dan mampu menyesuaikan diri dengan perkembangan yang ada. Sebagai seorang pendidik, kita juga harus selalu kreatif dan inovatif untuk mencari inovasi baru dalam pembelajaran. Salah satu inovasi dalam pembelajaran adalah dengan memanfaatkan aplikasi Google Docs. Makalah ini berdasarkan penelitian tindakan kelas tentang pemanfaatan aplikasi Google Docs untuk mendukung penggunaan teknik Peer-Review dalam pembelajaran menulis mahasiswa Pendidikan Bahasa Inggris Universitas Widya Dharma Klaten. Hasil penelitian menunjukkan teknik Peer-Review dengan memanfaatkan aplikasi Google Docs dalam pembelajaran menulis dapat 1) melatih mahasiswa untuk berfikir kritis, jeli, dan teliti saat menelaah tulisan temannya yang secara otomatis dapat meningkatkan kemampuan menulis mereka sendiri; 2) meningkatkan kemampuan berkolaborasi dan bekerja sama agar memiliki daya saing global di abad ke21; 3) memotivasi mahasiswa untuk aktif dalam menyelesaikan tugas menulis; 4) membuat pembelajaran di kelas menjadi lebih berarti dengan menciptakan situasi di kelas lebih hidup; 5) membuat mahasiswa merasa lebih menikmati dan aktif pada pembelajaran menulis; 6) menghemat penggunaan kertas; 7) memberikan kelonggaran kepada mahasiswa untuk kapanpun dan dimanapun mereka ingin mereview tulisan temannya tanpa harus terikat waktu dan tempat saat pembelajaran menulis di kelas; serta 8) dapat mendongkrak ketajaman analisis mahasiswa sehingga dapat dimanfaatkan pula pada bidang-bidang kajian lain.
\end{abstract}

Kata kunci: Teknik Peer-Review, Aplikasi Google Docs, Kemampuan Menulis

\section{PENDAHULUAN}

Perkembangan teknologi yang begitu pesat di era modern telah sangat membantu dalam berbagai aspek kehidupan, termasuk dalam dunia pendidikan. Era modern yang serba digital terbukti memudahkan dalam pelaksanaan pendidikan. Para pendidik dituntut untuk selalu aktif, kreatif, dan inovatif untuk menemukan strategi dalam mendukung 
pembelajaran. Salah satu pemanfaatan teknologi di dunia pendidikan adalah penggunaan berbagai aplikasi yang dapat di akses melalui daring. Aplikasi berbasis daring digunakan untuk memudahkan pembelajaran mandiri atau biasa disebut dengan student-centered; maksudnya peserta didik dituntut untuk aktif mencari informasi dan melakukan kegiatan dalam menyelesaikan tugas pembelajaran. Aplikasi daring yang digunakan dalam pembelajaran misalnya kamus online, Email, Plagiarism Checker, dan Spellogram.

Artikel ini membahas lebih kerucut tentang penggunaan aplikasi yang disediakan oleh Google, yaitu aplikasi Google Docs. Google Docs digunakan sebagai salah satu strategi pembelajaran inovatif untuk meningkatkan kemampuan menulis. Kemampuan menulis sering dijadikan objek penelitian karena kemampuan ini dianggap sebagai kemampuan berbahasa yang paling sulit untuk dikuasai oleh peserta didik (Rovimiyanti, 2008; Pranata 2013; dan Nasution \& Siregar, 2013). Hal tersebut juga dirasakan oleh mahasiswa Program Studi Bahasa Inggris, Universitas Widya Dharama Klaten. Kegiatan menulis dianggap sulit karena menulis merupakan suatu kegiatan yang produktif dan ekspresif sehingga harus terampil dalam memanfaatkan struktur bahasa dan kosa kata. Penelitian mengenai cara meningkatkan kemampuan menulis dengan berbagai metode juga telah dilakukan, seperti dengan memanfaatkan media web (Asri, 2011), diary (Ningrum \& Rita, 2013), dan journal (Safriana, Said, \& Waris, 2013). Akan tetapi penggunaan media tersebut juga mempunyai kelemahan, yaitu pembelajaran menulis dengan menggunakan media-media tersebut merupakan pembelajaran mandiri, sehingga belum memberikan kesempatan kepada peserta didik untuk bekerja sama atau berkolaborasi. Padahal kemampuan berkolaborasi menjadi salah satu kemampuan penting di era modern yang serba digital, karena kemampuan ini mendukung peserta didik untuk belajar berkomunikasi dan bekerja sama dengan baik dan handal.

Beberapa penelitian membuktikan bahwa aktivitas belajar dengan berkolaborasi terbukti dapat meningkatkan kemampuan peserta didik secara signifikan, diantaranya penelitian yang dilakukan oleh Alwasilah (2001), Sihire (2014), dan Togatorop (2015). Oleh sebab itu, penelitian ini juga mencoba untuk menggunakan pembelajaran kolaborasi untuk meningkatkan kemampuan menulis.

Pembelajaran kolaborasi yang digunakan dalam penelitian ini adalah pembelajaran dengan teknik Peer-Review dengan menggunakan aplikasi Google Docs yang diterapkan dalam penelitian tindakan kelas. Google Docs dapat diakses secara daring dan dapat berkolaborasi dengan jumlah anggota yang lebih banyak. Dokumen yang ada di Google Docs dapat dilihat, diedit, diberikan komentar, serta dibagikan ke beberapa orang yang diinginkan sehingga kegiatan ini sama dengan kegiatan diskusi tanpa harus melakukan tatap muka. Berbagai penelitian tentang pemanfaatan aplikasi Google Docs telah banyak dilakukan, diantaranya oleh Cholifah (2014), Setyawan, dkk (2014), Dharmawan dkk (2015), dan Pormes \& Utomo (2015). Dharmawan dkk (2015) menyimpulkan bahwa pembelajaran menggunakan Google Docs lebih praktis karena lebih mudah aplikasinya, tidak banyak waktu untuk memahaminya, serta menghemat buku tulis. Dharmawan, dkk (2015) juga menambahkan penggunaan aplikasi Google Docs 1) sangat praktis, efektif, dan efisien; 2) bisa berinteraksi dengan siswa atau guru secara online; 3) penggunaan waktu lebih efektif; 4) dapat memantau siswa meski waktu libur; 5) dapat berdiskusi tentang materi pelajaran; 6) dapat memantau kegiatan siswa secara real time dalam kerja kelompok, dan dapat menyelesaikan tugas lebih cepat karena tidak terpaku pada pertemuan kelas.

Pemanfaatan aplikasi Google Docs dalam penelitian ini mendukung 
pembelajaran menulis dengan teknik PeerReview. Teknik Peer-Review atau biasa di sebut teknik pengoreksian teman sejawat adalah sebuah pengajaran yang terfokus pada pengajaran menulis. Teknik ini adalah sebuah teknik kolaborasi yang dapat membuat peserta didik lebih aktif dalam belajar menulis dengan melakukan kerja sama antarteman untuk saling bertukar pikiran dan memberikan saran terhadap hasil tulisan mereka (Kustati \& Suhardi, 2014), serta membuat siswa merasa lebih menikmati dan aktif pada pembelajaran menulis (Nasution \& Siregar, 2013).

\section{TEKNIK PEER-REVIEW}

Peer-Review berasal dari kata peer yang berarti rekan sejawat dan review yang berarti telaah kembali, dengan demikian peer-review adalah telaah kembali suatu pekerjaan yang dilakukan oleh rekan sejawat (satu profesi). Peer-review sering kali disebut sebagai peer-feedback, peerresponse, atau peer-editing pada pengajaran bahasa (Gielen, dkk., 2010; Liu \& Hansen dalam Kustati dan Suhardi, 2014).

Dalam istilah bahasa Indonesia, peer-review biasa disebut sebagai penelaahan sejawat atau pengoreksian teman sejawat, yaitu suatu proses pemeriksaan atau penelitian suatu karya atau ide pengarang ilmiah oleh pakar lain di bidang tersebut. Penilaian sejawat bertujuan untuk membuat penelitian memenuhi standar disiplin ilmiah dan standar keilmuan pada umumnya. Pada pembelajaran bahasa, Peer-Review Technique adalah sebuah teknik pembelajaran ketika siswa dapat berbagi tulisan mereka dengan teman sejawat untuk mendapatkan umpan balik (feedback) dan kemudian menggunakannya untuk merevisi dan memperbaiki hasil tulisan mereka.

Teknik Peer-Review adalah bagian yang penting dari proses menulis. Kegiatan ini menurut Brown (2001: 348) memanfaatkan proses drafting (penyusunan awal) dan tahap revisi, dengan memperhatikan proses menulis yang terdiri dari empat elemen, yaitu perencanaan (planning), penyusunan awal (drafting), pengeditan (editing), dan revisi akhir (final revision). Melalui teknik tersebut, siswa melaksanakan keempat elemen dari proses menulis itu sendiri. Dalam penelitian ini kemampuan menulis peserta didik dinilai dari beberapa aspek dengan menggunakan Analytic Scale yang adopsi dari Brown \& Bailey dalam Brown (2004: 244-245), yaitu Organization (Introduction, Body, and Conclusion); Content (Logical development of ideas); Syntax (Grammar); Mechanics (Punctuation and spelling); dan Vocabularies (Style and Quality of expression).

Dengan menerapkan teknik PeerReview dalam pembelajaran akan membantu siswa untuk mengetahui kelebihan dan kekurangan atau apa saja yang terlewat dari tulisan mereka, sehingga mereka bisa merevisi dan memperbaikinya. Peer-review digunakan siswa untuk mencari sumber informasi selama proses menulis yang didapat dari komentar dan kritik guru, tutor, teman sejawat, atau editor pada draf mereka, baik dalam format tulisan maupun lisan (Hansen \& Liu dalam Kustati dan Suhardi, 2014). Teknik Peer-Review sebagai salah satu model pembelajaran kolaborasi dapat memotivasi dan meningkatkan partisipasi peserta didik untuk lebih percaya diri menunjukkan kemampuannya. Pengerjaan tugas kelompok juga membuat masingmasing peserta didik serius dan bertanggung jawab atas tugas yang diberikan. Hal ini sesuai dengan teori yang dikemukan oleh Richard \& Rodger (2000: 229), Bukart (2006), dan Littlewood (1981: 17) pada Sholihah (2011) yang mengatakan bahwa pemberian tugas dapat memotivasi peserta didik dalam pembelajaran bahasa dan mendukung pembelajaran karena dapat memenuhi tujuan akhir yang diinginkan peserta didik, yaitu kemampuan menulis dalam bahasa Inggris.

\section{APLIKASI GOOGLE DOCS}

Google Docs adalah salah satu layanan dari Google berbasis web gratis yang menyediakan layanan pengolahan 
kata, presentasi, angket, formulir, dan penyimpanan data. Penggunaan Google Docs sama seperti microsoft word, excel, atau power-point, tetapi penggunaannya secara online. Aplikasi Google Docs tidak perlu software khusus sehingga memungkinkan kita membuat dan mengedit teks dokumen langsung dari web browser. Data yang dibuat dan diedit akan disimpan via browser, sehingga file yang dibuat ada di server-nya google. Setiap perubahan pada dokumen disimpan secara otomatis. Data Google Docs biasanya di share link-nya, jadi bisa dikolaborasikan dan diedit bersama-sama. Dokumen yang dibuat bisa dilihat, dikerjakan, dan diedit secara bersama-sama dengan beberapa orang di waktu yang sama. Untuk melihat semua dokumen yang sudah di edit di Google Docs, bisa dengan mengunjungi link http://docs.google.com/, biasanya attachment email gmail juga otomatis ada di Google Docs, dan kadang otomatis juga ada di google drive.

Kelebihan Google Docs adalah kita dapat menyimpan dokumen-dokumen yang kita miliki di google.co.id sebagai tempat penyimpanan data cadangan kita. Jika laptop atau komputer kita terkena virus, kita tidak perlu kebingungan karena sudah menyimpan data-data kita di google.docs. File yang disimpan masih ada dan tidak hilang sedikitpun. Kita bisa menyembunyikan file-file rahasia kita selama kita tidak memberitahu orang lain akun dan password gmail kita.

\section{TEKNIK PEER-REVIEW DENGAN APLIKASI GOOGLE DOCS}

Langkah-Langkah Penerapan Teknik Peer Review dengan Menggunakan Aplikasi Google Docs

Langkah-langkah penerapan teknik Peer Review dalam pembelajaran menulis dengan memanfaatkan aplikasi Google Docs adalah sebagai berikut:

a. Setiap peserta didik diminta untuk membuat akun Google terlebih dahulu, kemudian menginstal aplikasi Google Docs di laptop atau smartphone masing-masing.

b. Pembelajaran menulis menggunakan group discussion dengan membagi peserta didik menjadi beberapa kelompok yang terdiri dari 5-6 orang peserta.

c. Tiap kelompok diberi tugas untuk membuat sebuah karangan.

d. Pengerjaan tugas dilakukan secara bersama-sama dalam diskusi kelompok mulai dari pemilihan judul, pembuatan draf awal, sampai penyempurnaan hasil karangan.

e. Karangan yang masih dalam proses penulisan di bagi (share) ke semua anggota kelompok menggunakan aplikasi Google Docs untuk mendapatkan saran dan review dari antar anggota kelompok, termasuk dosen yang mengampu untuk mengecek keaktifan dan keberlanjutan sejauh mana tugas telah dilaksanakan.

f. Masing-masing anggota kelompok saling memberikan koreksi, saran, dan ide pada karangan tersebut;

g. Setelah pembelajaran di kelas berakhir, peserta didik diminta untuk melanjutkan diskusi di luar jam pembelajaran dikelas dengan menggunakan aplikasi Google Docs.

h. Hasil karangan yang telah didiskusikan antar anggota grup melalui teknik Peer-Review dan juga yang telah dikoreksi dan diberi saran oleh dosen pengampu dengan menggunakan aplikasi Google Docs di presentasikan pada pertemuan di kelas dan diskusikan dengan grup yang lain untuk menerima kritik, saran, maupun pertanyaan sebagai bagian dari teknik Peer-Review.

i. Hasil akhir karangan yang telah diperbaiki setelah melalui proses diskusi dan presentasi kemudian dikumpulkan sebagai hasil tugas. 
Hasil Penerapan Teknik Peer-Review dengan Menggunakan Aplikasi Google Docs

Teknik Peer Review dengan menggunakan aplikasi Google Docs yang diterapkan pada peserta didik dalam pembelajaran menulis memiliki pengaruh yang signifikan terhadap meningkatnya nilai rata-rata peserta didik. Peningkatan kemampuan menulis dapat dilihat dari peningkatan nilai rata-rata dari siklus ke siklus. Nilai rata-rata pada saat pre-test adalah 63,1; siklus I 68,35; siklus II 73,2; dan siklus III 81,55.

Sedangkan peningkatan kemampuan menulis dilihat dari masing-masing aspek adalah sebagai berikut:

Tabel 1. Peningkatan Kemampuan Menulis pada Masing-Masing Aspek

\begin{tabular}{|c|c|c|c|c|}
\hline $\begin{array}{c}\text { Aspek } \\
\text { Menulis }\end{array}$ & $\begin{array}{c}\text { Pre- } \\
\text { Test }\end{array}$ & $\begin{array}{c}\text { Siklus } \\
\text { I }\end{array}$ & $\begin{array}{c}\text { Siklus } \\
\text { II }\end{array}$ & $\begin{array}{c}\text { Siklus } \\
\text { III }\end{array}$ \\
\hline Organization & 12,4 & 13,75 & 14,75 & 16,45 \\
\hline Content & 19,5 & 20,25 & 21,7 & 25 \\
\hline $\begin{array}{c}\text { Syntax / } \\
\text { Grammar }\end{array}$ & 15,25 & 16,75 & 18,25 & 20,25 \\
\hline Mechanics & 2,85 & 3,5 & 3,5 & 3,95 \\
\hline Vocabulary & 13,1 & 14,1 & 15 & 15,9 \\
\hline
\end{tabular}

Tabel 2.Persentase Nilai Rata-Rata Masing Aspek Tiap Siklus

\begin{tabular}{|c|c|c|c|c|}
\hline $\begin{array}{c}\text { Aspek } \\
\text { Menulis }\end{array}$ & $\begin{array}{c}\text { Pre- } \\
\text { Test }\end{array}$ & $\begin{array}{c}\text { Siklus } \\
\text { I }\end{array}$ & $\begin{array}{c}\text { Siklus } \\
\text { II }\end{array}$ & $\begin{array}{c}\text { Siklus } \\
\text { III }\end{array}$ \\
\hline Organization & $62 \%$ & $69 \%$ & $74 \%$ & $82 \%$ \\
\hline Content & $65 \%$ & $68 \%$ & $72 \%$ & $83 \%$ \\
\hline $\begin{array}{c}\text { Syntax } / \\
\text { Grammar }\end{array}$ & $61 \%$ & $67 \%$ & $73 \%$ & $81 \%$ \\
\hline Mechanics & $57 \%$ & $70 \%$ & $70 \%$ & $79 \%$ \\
\hline Vocabulary & $66 \%$ & $71 \%$ & $75 \%$ & $80 \%$ \\
\hline
\end{tabular}

Berdasarkan nilai yang didapat dari pre-test dan masing-masing siklus, dapat dilihat adanya peningkatan dalam kemampuan menulis pada pembuatan sebuah karangan. Sebelum diterapkan teknik Peer-Review dengan menggunakan aplikasi Google Docs, peserta didik masih sulit untuk mengungkapkan ide-nya (content), karena kurangnya perbendaharaan kata (vocabulary), ide yang dituangkan dalam tulisan masih melompat- lompat atau belum runtun (organization), masih sering dijumpai beberapa kesalahan pada penerapan grammar, tenses, dan tanda baca (punctuation). Setelah penerapan teknik Peer-Review dengan memanfatkan aplikasi Google Docs telah terbukti dapat meningkatkan beberapa aspek tersebut.

\section{Pembahasan}

Teknik Peer-Review dengan memanfaatkan aplikasi Google Docs dalam pembelajaran menulis memiliki keunggulan sebagai berikut:

a. Dapat melatih mahasiswa untuk berfikir kritis, jeli, dan teliti saat menelaah tulisan temannya yang secara otomatis dapat meningkatkan kemampuan menulis mereka sendiri.

Inilah yang disebut dengan teknik PeerReview yang dapat mendongkrak daya kritis peserta didik karena memberikan kesempatan peserta didik untuk mencari sumber informasi selama proses menulis yang didapat dari komentar/pendapat, saran, dan kritik antar anggota kelompok dan dosen pengampu (Hansen \& Liu dalam Kustati dan Suhardi, 2014).

b. Dapat meningkatkan kemampuan berkolaborasi dan bekerja sama agar memiliki daya saing global di abad ke21.

Pemanfaatan aplikasi Google Docs dalam mendukung teknik Peer-Review dalam pembelajaran menulis dapat meningkatkan kemampuan berkolaborasi peserta didik, meningkatkan hubungan sosial, sikap kerja sama, dan saling menghargai. Kolaborasi dalam bentuk grup dalam pembelajaran yang menekankan pada proses penyelesaian masalah dan berfikir bersama secara efektif dapat lebih memberdayakan kemampuan menulis siswa (Hadiyanto dan Sundari, 2011), memberikan kesempatan siswa yang lebih mahir menulis (yang mungkin tidak terdeteksi dan kurang tertantang dengan kegiatan menulis yang hanya fokus pada teori) untuk bertindak sebagai reviewer mengajari 
dan membagi ilmunya kepada siswa yang lain (Nelson, 2000).

c. Dapat memotivasi peserta didik untuk aktif dalam menyelesaikan tugas menulis.

Teknik Peer-Review dengan menggunakan aplikasi Google Docs dapat meningkatkan partisipasi peserta didik, lebih percaya diri menunjukkan kemampuannya. Tugas kelompok membuat masing-masing peserta didik serius dan bertanggung jawab atas tugas yang diberikan. Hal ini sesuai dengan teori yang dikemukan oleh Richard \& Rodger (2000: 229), Bukart (2006), dan Littlewood (1981: 17) pada Sholihah (2011) yang mengatakan bahwa pemberian tugas dapat memotivasi peserta didik dalam pembelajaran bahasa dan mendukung pembelajaran karena dapat memenuhi tujuan akhir yang diinginkan peserta didik, yaitu kemampuan menulis dalam bahasa Inggris.

d. Dapat membuat pembelajaran di kelas menjadi lebih berarti dengan menciptakan situasi di kelas lebih hidup.

Penerapan teknik Peer-Review membuat peserta didik memperhatikan dan melaksanakan tugas dari dosen dengan baik, serta menikmati dalam proses pembelajaran. Kegiatan ini juga meningkatkan kreativitas dosen, sikap, tanggapan, dan pemahaman siswa tentang materi yang diajarkan. Pembelajaran ini sangat menarik dan efektif di antaranya karena memberikan kesempatan kepada peserta didik untuk menggunakan bahasa secara optimal untuk saling berkomunikasi dan berdiskusi mengenai tugas yang diberikan (Harmer dalam Hadiyanto \& Sundari, 2011).

e. Dapat membuat mahasiswa merasa lebih menikmati dan aktif pada pembelajaran menulis.

Penerapan teknik Peer-Review membuat siswa merasa lebih menikmati dan aktif pada pembelajaran menulis Nasution \& Siregar (2013).

f. Dapat menghemat penggunaan kertas. Pembelajaran menggunakan Google Docs lebih praktis karena lebih mudah aplikasinya dan tidak banyak waktu untuk memahaminya, serta menghemat buku tulis (Dharmawan, dkk. (2015).

g. Dapat memberikan kelonggaran kepada mahasiswa untuk kapanpun dan dimanapun mereka ingin mereview tulisan temannya tanpa harus terikat waktu dan tempat saat pembelajaran menulis di kelas.

Penggunaan aplikasi Google Docs memberikan keunggulan dalam penggunaan waktu yang lebih efektif karena memungkinkan peserta didik untuk bisa berinteraksi dan berdiskusi dengan peserta didik yang lain dan dosen secara online sehingga dosen juga dapat memantau kegiatan peserta didik secara real time meski waktu libur (Dharmawan, dkk., 2015). Hal ini memudahkan pemantauan oleh dosen, tidak hanya pada saat pembelajaran di kelas. Proses Peer-Review pada tugas karangan mereka terus berjalan dengan menggunakan aplikasi Google Docs meskipun tiap-tiap anggota kelompok tidak bertemu langsung. Inilah salah satu keunggulan penggunaan aplikasi Google Docs yang tidak terpaku waktu pembelajaran sehingga peserta didik dapat menyelesaikan tugas lebih cepat karena tidak terpaku pada pertemuan kelas.

h. Dapat mendongkrak ketajaman analisis mahasiswa sehingga dapat dimanfaatkan pula pada bidang-bidang kajian lain.

\section{SIMPULAN}

Berdasarkan pembahasan diatas, dapat ditarik kesimpulan bahwa penggunaan teknik Peer-Review terbukti dapat mendongkrak ketajaman analisis peserta didik sehingga dapat melatih mereka untuk berfikir kritis, jeli, dan teliti saat menelaah tulisan temannya yang secara otomatis dapat 
meningkatkan kemampuan menulis mereka sendiri. Disamping itu, pemanfaatan teknologi dalam pembelajaran dengan menggunakan aplikasi Google Docs dapat sangat membantu dalam proses belajar mengajar terutama dapat meningkatkan keterampilan menulis. Aplikasi Google Docs memberikan kelonggaran kepada mahasiswa untuk kapanpun dan dimanapun mereka ingin me-review tulisan temannya tanpa harus terikat waktu dan tempat saat pembelajaran menulis di kelas.

Teknik Peer-Review dengan

memanfaatkan teknologi seperti aplikasi
Google Docs juga dapat meningkatkan daya kritis, sikap jeli dan teliti, serta kemampuan berkolaborasi peserta didik yang dapat membekali mereka dalam berkolaborasi dan bekerja sama agar memiliki daya saing global di abad ke-21. Oleh karena itu, pemanfaatan aplikasi Google Docs dalam penerapan teknik Peer-Review merupakan alternatif piranti kolaborasi dalam menulis yang terbukti mampu meningkatkan kemampuan menulis sehingga dapat juga diterapkan pada bidang pembelajaran yang lain.

\section{DAFTAR PUSTAKA}

Alwasilah, A. Chaedar. (2001). Empowering College Student Writers Through Collaboration. Journal Teflin Vol XII, No. 1 February (2001). Hal. 1-13.

Asri, A. N. (2011). Using Web Folio to Improve Student's Writing Skills. Jurnal Ilmu Pendidikan, 17(5), 361-367.

Brown, Douglas H. 2001. Teaching by Principles: An interactive approach to language pedagogy, second edition.

. 2004. "Language Assessment: Principles and Classroom Practices" Pearson Education, NY, USA

Cholifah, Maria. (2014). Teaching Writing to Build Students' Character by Using Google Docs. Jurnal Inspirasi, Vol 4, No 1 (2014): Januari 2014

Dharmawan, Ramona, Rupiasih, \& Nilakusmawati. (2015). Pemanfaatan Aplikasi Google Docs Sebagai Media Pembinaan Karya Ilmiah Remaja. Fakultas MIPA Universitas Udayana. Prosiding Seminar Nasional Teknologi Informasi dan Aplikasinya (SNATIA) hal. 45-48.

Hadiyanto, \& Sundari, W. (2011). The Effectiveness of Student Grouping In Endorsing English Writing Skill Mastery. Lensa, 1(1), 51-56.

Kustati \& Yuhardi, The Effect of the Peer-Review Technique on Students ${ }^{\text {ee }}$ Writing Ability. STUDIES IN ENGLISH LANGUAGE AND EDUCATION, Volume 1, Number 2, September 2014. Hal. 71-81.

Nahdi, Muhammad. (2011). Improving Students' Writing Ability by Using Peer Editing Technique.

Nasution, N.S.R., \& Siregar, Masitowarni (2013). Improving Students' Writing Recount Achievement Through Peer Review Technique. GENRE Journal of Applied Linguistics of FBS Unimed, Vol 2. No 1 (2013).

Nelson, Stephanie. (2000). Teaching Collaborative Writing and Peer Review Techniques to Engineering and Technology Undergraduates. Frontier in Education Conference, 2000. FIE 2000. 30th Annual. Diambil dari: ieeexplore.ieee.org

Ningrum, V., \& Rita, F. (2013). Improving Writing Skill in Writing Recount Text Through Diary Writing. Journal of English Language Teaching Society (ELTS), 1(1), 1-13.

Pranata, Alit Kusuma. (2013). Penggunaan Teknik 3-P untuk Meningkatkan Kemampuan Menulis Berita Berbasis 5W + 1H Siswa Kelas VIII A SMP Negeri 7 Singaraja. Jurnal Jurusan Pendidikan Bahasa dan Sastra Indonesia Vol 1, No. 1 (2013).

Rovimiyanti. (2008). Kemampuan Menulis Paragraf Siswa Kelas X SMK Taruna Bhakti 
Malang Tahun Ajaran 2007/2008. Jurnal Artikulasi Vol 5, No. 1 (2008): Februari.Hal. 230-242.

Safriana, Said, M. M., \& Waris, A. (2013). Developing Writing Skill through Journals. Journal of English Language Teaching Society (ELTS), 1(1), 1-10.

Setyawan, G. Y, Martono, Rochsantiningsih, D. (2014). Optimizing Google Docs to Improve Students' Writing Skill of Descriptive Text. English Education Vol 2, No 2 (2014). Januari 2014.

Sihire, Pitra. (2014). Pengaruh Pembelajaran Kolaboratif terhadap Kemampuan Menulis Teks Eksposisi Siswa Kelas X SMA Negeri 1 Balige Tahun Pembelajaran 2013/2014. Jurnal Bahasa Vol 3, No 3 (2014): Desember 2014.

Sholihah, Umi. (2011). 'Improving Students' Writing Ability Using Task - Based Language Teaching (TBLT) (A Classroom Action Research at the Students of Class X TKJ 1 SMKN 2 Sragen in the 2010/2011 Academic Year)". https://digilib.uns.ac.id.

Togatorop, Erikson. (2015) Teaching Writing with a Web Based Collaborative Learning . International Journal of Economics and Financial Issues (IJEFI), 2015, 5(Special Issue) 247-256. $2^{\text {nd }}$ AFAP INTERNATIONAL CONFERENCE ON ENTERPRENEURSHIP AND BUSINESS MANAGEMENT (AICEBM 2015), 10-11 January 2015, Universiti Teknologi Malaysia, Kuala Lumpur, Malaysia.

Pormes R. \& Utomo, W. H. (2015) Analisis Perbandingan Could Document pada Eyeos dan Google Docs. Jurnal Sistem Komputer Vol 5, No 1 (2015): Mei 2015. 